S. Afr. J. Agric. Ext.,

Vol. 44, No. 2, 2016: $121-135$

Masuka, Matenda, Chipomho, Mapope,

Mupeti, Tatsvarei \& Ngezimana.

DOI: http://dx.doi.org/10.17159/2413-3221/2016/v44n2a406

(Copyright)

\title{
MOBILE PHONE USE BY SMALL-SCALE FARMERS: A POTENTIAL TO TRANSFORM PRODUCTION AND MARKETING IN ZIMBABWE.
}

Masuka, B., ${ }^{21}$ Matenda, T., ${ }^{22}$ Chipomho, J., ${ }^{23}$ Mapope, N., ${ }^{24}$ Mupeti, S., ${ }^{25}$ Tatsvarei, S. ${ }^{26} \&$ Ngezimana, W. ${ }^{27}$

\section{ABSTRACT}

Smallholder farmers are major contributors of horticultural produce. Women's contribution is noteworthy. Meeting market demand on time and avoiding market 'floods' is a challenge among communal farmers, leading to post harvest losses partly due to lack of information and uninformed decision making. Mobile phones have potential to connect farmers to markets, close the information gap and enable informed decisions. Currently most farmers target a few markets leading to market 'floods', low prices and fresh produce deterioration while some potential markets remain untapped. A survey conducted in 2015 covering 131 farmers in Svosve-Wenimbi, Marondera district of Mashonaland East province in Zimbabwe evaluated mobile phone ownership and use in farming; and its potential in transforming production and marketing. High literacy and mobile phone ownership of $95.32 \%$ and $94.45 \%$ respectively was reported, with $16 \%$ already accessing advisory services over mobile phone. $51.1 \%$ utilised various mobile phone services including accessing market information on inputs and produce, advisory services, weather data, mobile phone money transfers for transaction and crop insurance. By using mobile phones farmers made informed decisions and saved time and transport cost. Mobile phone ICT can promote better production, marketing, food security and livelihoods and more farmers may adopt the technology.

Keywords: small holder agriculture, marketing, mobile phones, women, Zimbabwe, extension implications.

\section{ABBREVIATIONS AND ACRONYMS}

ICT: Information and Communications Technologies

\section{INTRODUCTION}

There has been rapid transformation and growth in the use of ICT including mobile phones in Zimbabwe and Africa as a whole in the recent years (Jensen, 2001; eTransform AFRICA, 2012). Unlike elsewhere in some Sub-Saharan African countries where limited infrastructure and trained personnel as well as general population literacy draw back the adoption of ICTs

\footnotetext{
${ }^{21}$ University of Zimbabwe, Marondera College of Agricultural Science and Technology P. Box 35, Marondera, Zimbabwe. Email: trimasuka@gmail.com

22 MercyCorps, 73 Harare drive Mt Pleasant, Harare, Zimbabwe. thmatenda@ gmail.com

23 University of Zimbabwe, Marondera College of Agricultural Science and Technology P. Box 35, Marondera, Zimbabwe. Email: jusychipomho@gmail.com

24 University of Zimbabwe, Marondera College of Agricultural Science and Technology P. Box 35, Marondera, Zimbabwe. Email: nmapope@gmail.com

25 University of Zimbabwe, Marondera College of Agricultural Science and Technology P. Box 35, Marondera, Zimbabwe. Email: mupetis@gmail.com

26 Department of Agricultural Economics and Extension, University of Fort Hare, Alice 5700, South Africa. University of Zimbabwe, Marondera College of Agricultural Science and Technology P. Box 35, Marondera, Zimbabwe. Email: tatsvarei.simbarashe@gmail.com

27 University of Zimbabwe, Marondera College of Agricultural Science and Technology P. Box 35, Marondera, Zimbabwe. Email: wonderjohnngezimana@yahoo.com
} 
S. Afr. J. Agric. Ext.,

Vol. 44, No. 2, 2016: $121-135$

Masuka, Matenda, Chipomho, Mapope,

Mupeti, Tatsvarei \& Ngezimana.

DOI: http://dx.doi.org/10.17159/2413-3221/2016/v44n2a406

(Copyright)

(Ewing, Quigless, Chevrolier, Verghese \& Leenderste, 2014), Zimbabwe has the infrastructure, with $6900 \mathrm{~km}$ optic fibre connections, three major mobile service providers (POTRAZ, 2014; TECHZIM, 2015), high literacy rate of 98\% (ZIMSTATS, 2011) and high mobile network subscription. By 2014 mobile phone subscription rate was 106\% (POTRAZ, 2014; TECHZIM, 2014) that was characterized by some dual Sims phones and multiple phone ownership, with $47.5 \%$ (6.1 million) internet subscribers of which $99 \%$ is accessed on mobile phones (POTRAZ, 2014; TECHZIM, 2015). Zimbabwe has a population of 15.5 million (World Bank, 2015) with 70\% living in the rural area (UNICEF, 2015) depending on agriculture for food security and a livelihood (FAO, 2015). According to Technomag (2014) mobile phone subscription in the rural population was $63 \%$ in 2013. Mobile technology can potentially transform all forms of business including agriculture (Jensen, 2001; Deloitte, 2012; Irefin, Abdu-Azeez \& Tijani, 2012; World Bank, 2012; Ewing et al., 2014; Oladele, 2015). Traditionally, communication in rural Zimbabwe has always been limited but mobile ICT has significantly connected these areas to others locally, regionally and internationally. Mobile ICT has the potential of improving production among rural area small holder farmers by overcoming the traditional isolation (Nyamba \& Mlozi, 2012; Oladele, 2015).

Agriculture plays a pivotal role in Zimbabwe's socio-economic development as well as food security and has the potential to significantly reduce poverty, enhance economic growth and consolidate economic stability. It is the major backbone of the country, contributing close to 16\% towards the GDP in 2010 (FAO, 2010). In 2013 and 2014 agriculture contributed 12\% and $14 \%$ respectively towards value added GDP (World Bank, 2015). Seventy-eight percent of the population living in rural areas is involved in small holder farming for food security and a livelihood (FAO, 2015). The rural population rely on agriculture as subsistence producers or agriculture workers for food security and a livelihood (FAO, 2006). Various agriculture produce from the small holder and commercial farming systems provides food for the nation, raw materials for the industry and agriculture exports playing an important role in food security and the economy of the nation. Agriculture therefore provides employment to the rural population as well as in secondary agriculture industries. It is essential that farmers access advisory services and market information for both inputs and produce for them to make informed decisions. Mobile phones enable farmers to get such information and make informed decisions (Tadesse \& Bahiigwa, 2015). It is essential to raise awareness and promote the use of this ICT platform among small holder farmers to keep them up to date on weather, farming advice and markets for informed decision, better planning and improved production.

Research done in Ethiopia, Uganda, Tanzania and China has shown that mobile phones can be used to provide information to the farmers and rural residents through SMS and multimedia-supported systems (Martin \& Abbott, 2008; Wei \& Zhang, 2008; Nyamba \& Mlozi, 2012; Chhachhar, Qureshi, Khushk, \& Maher, 2014; Tadesse \& Bahiigwa, 2015). This has been made possible through both public and private sector initiatives. According to Martin \& Abbott, (2008) and Wei \& Zhang (2008), mobile phone use offers real benefits to rural residents in the area of connectivity to the outside world as well as reduced unnecessary commuting to urban centres. From a socio-economic point of view, mobile phones enable easier and more effective sharing of information and knowledge among individuals, with institutions, suppliers and markets. With information on the supplies markets and prices, markets for products and product prices, weather data and advice farmers are able to make informed decisions (Nyamba \& Mlozi, 2012; Tadesse \& Bahiigwa, 2015). In a study by Martin \& Abbott (2008), mobile phone use was reported to enable farmers to consult with extension advisory and veterinary consultants on daily basis as well as in emergency cases 
S. Afr. J. Agric. Ext.,

Vol. 44, No. 2, 2016: $121-135$

DOI: http://dx.doi.org/10.17159/2413-3221/2016/v44n2a406

like when livestock get sick. Elsewhere including Zimbabwe, farmers make and receive payments as well as insure crops using mobile services (Econet, 2015). By consulting remotely on mobile phones for supplies and product markets, prices, for advice as well as by using mobile financial transactions, farmers save time and finances that would have been used on travelling (Deloitte, 2012; Nyamba \& Mlozi, 2012).

Information management plays a major role in today's world of information abundance and outflow. Information technologies represent means of distributing information and knowledge in much faster and efficient way (Krishan, 2000). This has been noted to help farmer groups and extension advisors to coordinate meetings and to seek opinions of members who are not present for the meeting (Martin \& Abbott, 2008). Armed with information farmers make informed decision, may produce better and get better markets and prices. The objectives of this study, therefore, were to i) describe the Svosve-Wenimbi farming system and ii) evaluate mobile phone ownership among the Svosve-Wenimbi area small scale farmers iii) investigate the awareness of farmers on the usefulness of mobile phones in farming and iv) to establish if farmers are already using mobile phones for agribusiness and advisory services. This study helps to evaluate the prospect in the use of mobile telephones among farmers as a tool of information technology in production and marketing.

\section{RESEARCH METHODOLOGY}

A key informant interview was conducted in the Svosve-Wenimbi farming community of Marondera district. This was followed up with a farmer survey. For comparison between genders, the farmer survey included both male and female farmers from the area studied. The interviews and surveys were conducted from July 2015 to September 2015. Stratified random sampling was used. The area was stratified into wards (four). At least 30 farmers were randomly picked from each ward and interviewed. A total of 131 farmers were interviewed. The data collected was captured, processed and analysed using the statistical package for social sciences (SPSS).

\subsection{Population description}

Descriptive statistics were generated to describe the population and farming system. Chisquare test was done to evaluate mobile phone ownership and use in agribusiness or for farming purposes.

\subsection{The Logit Model}

The study uses a binomial logit model to analyse the socioeconomic factors affecting the households' decision to adopt mobile ICTs in agriculture. The dependent variable is dichotomous i.e. households decision to adopt or not adopt mobile ICT in agriculture. The binary logit model in this case is appropriate because it considers the relationship between a binary dependent variable and a set of independent variables (Fosu-Mensah, Vlek \& MacCarthy, 2012). The model uses a logit curve to transform binary responses into probabilities within the $0-1$ interval. In the logit model the parameter estimates are linear and assume a normally distributed error term $(\mu)$. The specification of the model is as follows:

$\mathrm{Y}=f\left(\mathrm{X}_{1}, \mathrm{X}_{2}, \mathrm{X}_{3}, \mathrm{X}_{4}, \mathrm{X}_{5}, \mathrm{X}_{6}, \mathrm{X}_{7}, \mathrm{X}_{8}\right)$ 
S. Afr. J. Agric. Ext.,

Vol. 44, No. 2, 2016: $121-135$

DOI: http://dx.doi.org/10.17159/2413-3221/2016/v44n2a406
Masuka, Matenda, Chipomho, Mapope,

Mupeti, Tatsvarei \& Ngezimana.

Where: $Y=$ adoption status $(1=$ adopted, $0=$ not adopted $), X_{1}=$ gender $(1=$ male, $0=$ female $)$ $\mathrm{X}_{2}=$ age, $\mathrm{X}_{3}=$ level of education, $\mathrm{X}_{4}=$ marital status, $\mathrm{X}_{5}=$ cattle owned, $\mathrm{X}_{6}=$ types of crops grown ( $1=$ commercial, $0=$ consumption $), X_{7}=$ source of extension $(1=$ public, $0=$ otherwise $)$, $\mathrm{X}_{8}=$ farm income as described in Table 1 .

Table 1: Description of variables expected signs of model

\begin{tabular}{|c|c|c|c|}
\hline Variable & Relationship with dependent variable & Expected & sign \\
\hline Gender & $\begin{array}{l}\text { Females are quick to adopt new ideas and } \\
\text { are more likely to use ICT than the male } \\
\text { counterparts (male }=1, \text { female }=0 \text { ) }\end{array}$ & Negative & - \\
\hline Age & $\begin{array}{l}\text { Young farmers are quick to understand and } \\
\text { accept new ideas and are therefore more } \\
\text { likely to adopt ICT than older farmers. }\end{array}$ & Negative & - \\
\hline Level of education & $\begin{array}{l}\text { Education increases the probability of } \\
\text { adopting mobile ICT in agriculture as it is } \\
\text { associated with being open minded and the } \\
\text { ability to embrace positive change. The } \\
\text { variable used is the total number of years of } \\
\text { education. }\end{array}$ & Positive & + \\
\hline Marital status & $\begin{array}{l}\text { This could be either positive or negative. } \\
\text { (married }=1 \text {, otherwise }=0 \text { ) }\end{array}$ & $\begin{array}{l}\text { Positive/ } \\
\text { negative }\end{array}$ & $+/-$ \\
\hline $\begin{array}{l}\text { Number of cattle } \\
\text { owned }\end{array}$ & $\begin{array}{l}\text { Cattle are an indication of the level of } \\
\text { wealth and it is expected that the higher it is, } \\
\text { the higher the use of mobile ICTs. }\end{array}$ & Positive & + \\
\hline $\begin{array}{l}\text { Types of crops grown/ } \\
\text { commercial activities }\end{array}$ & $\begin{array}{l}\text { Farmers growing more cash crops are more } \\
\text { likely to use ICTs as the need to } \\
\text { communicate with markets compared to } \\
\text { those growing for own consumption, } \\
\text { (commercial crops-tobacco, horticulture }=1 \text {, } \\
\text { otherwise }=0 \text { ) }\end{array}$ & Positive & + \\
\hline Source of extension & $\begin{array}{l}\text { Those receiving private extension are more } \\
\text { likely to use mobile ICT (private } \\
\text { extension }=1 \text {, otherwise }=0 \text { ) }\end{array}$ & $\begin{array}{l}\text { Positive/ } \\
\text { negative }\end{array}$ & $+/-$ \\
\hline Income & $\begin{array}{l}\text { The higher the farm income, the higher is } \\
\text { access to markets and more use of ICTs. } \\
\text { The income taken is the sum of the on-farm } \\
\text { and non-farm income as mobile } \\
\text { technologies can be bought from any of the } \\
\text { two. }\end{array}$ & Positive & + \\
\hline
\end{tabular}

\section{RESULTS AND DISCUSSION}

\subsection{Demography}

Of the 131 farmers interviewed, $51.15 \%$ were male and $48.85 \%$ were female (Figure 1 ). The farmers' ages ranged from 16 years to over 90 years (Figure 2). This shows that the survey covered a cross section of the farming community in Svosve-Wenimbi area of Marondera District. Of the respondents $70 \%$ were married while $30 \%$ were single (Figure 3), widowed or separated/ divorced $(\mathrm{p}<0.001)$. As shown in Figure 4, out of the $70 \%$ married farmers, 
S. Afr. J. Agric. Ext.,

Vol. 44, No. 2, 2016: $121-135$

DOI: http:/

Mupeti, Tatsvarei \& Ngezimana.

$94.4 \%$ were farming together $(\mathrm{p}<0.001)$ showing the high dependence of the rural community on agriculture. This indicates small holder farming is paramount for the rural population as reported by FAO (2015). It is therefore important to support optimal production in small holder farming for food security and to promote livelihoods. Extension is one of the critical areas that will promote better production in this farming system.

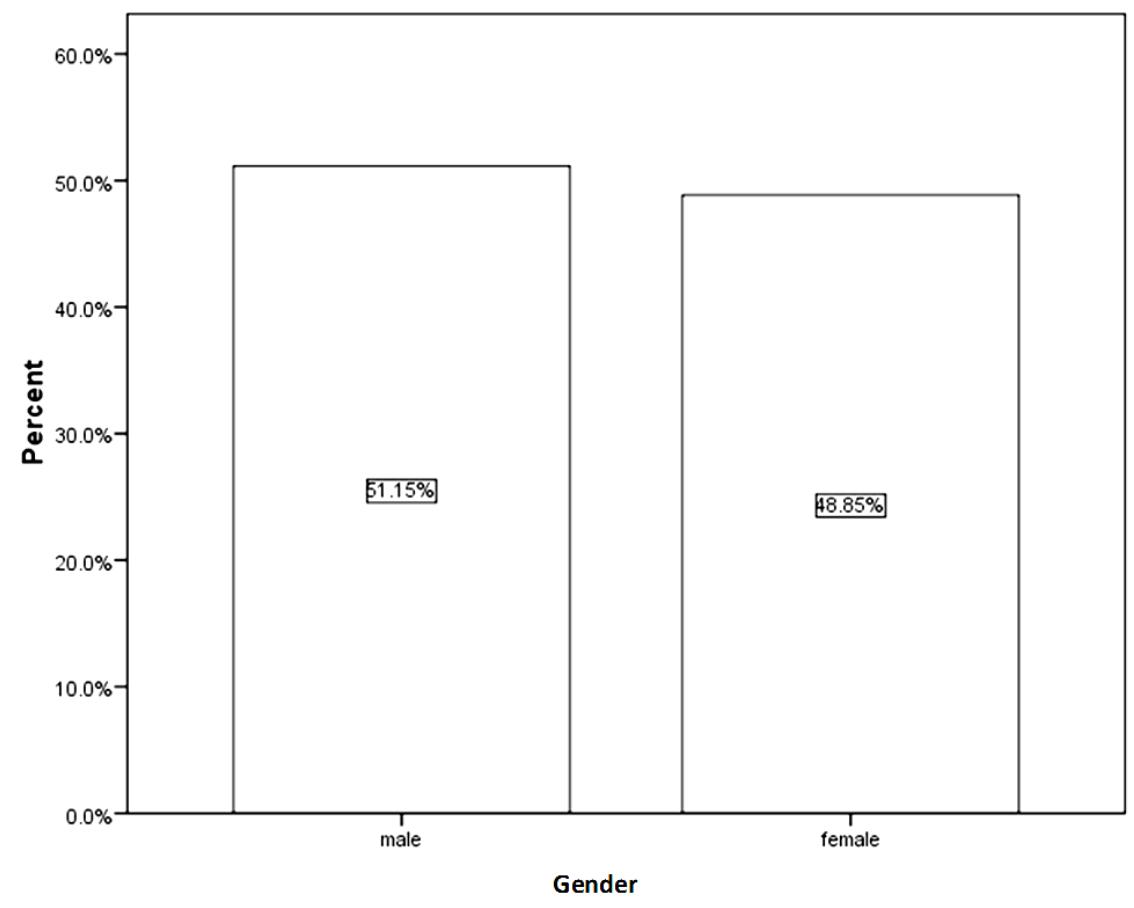

Figure 1: Gender of farmers interviewed

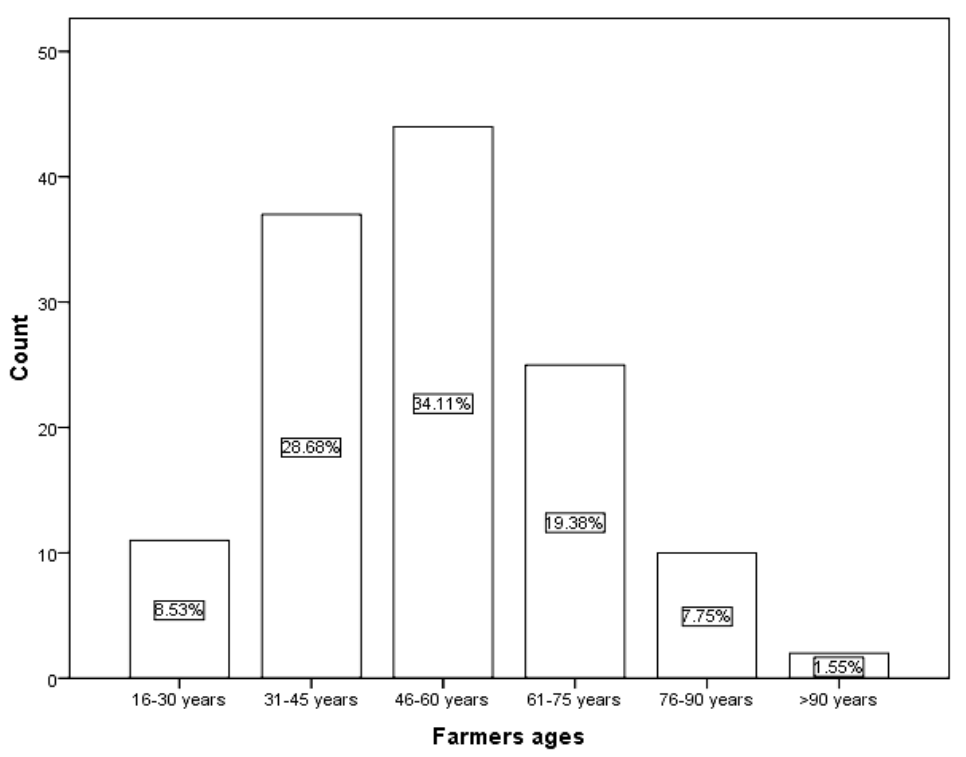

Figure 2: Age of farmers interviewed 
S. Afr. J. Agric. Ext.,

Vol. 44, No. 2, 2016: $121-135$

DOI: http://dx.doi.org/10.17159/2413-3221/2016/v44n2a406

Masuka, Matenda, Chipomho, Mapope, Mupeti, Tatsvarei \& Ngezimana.

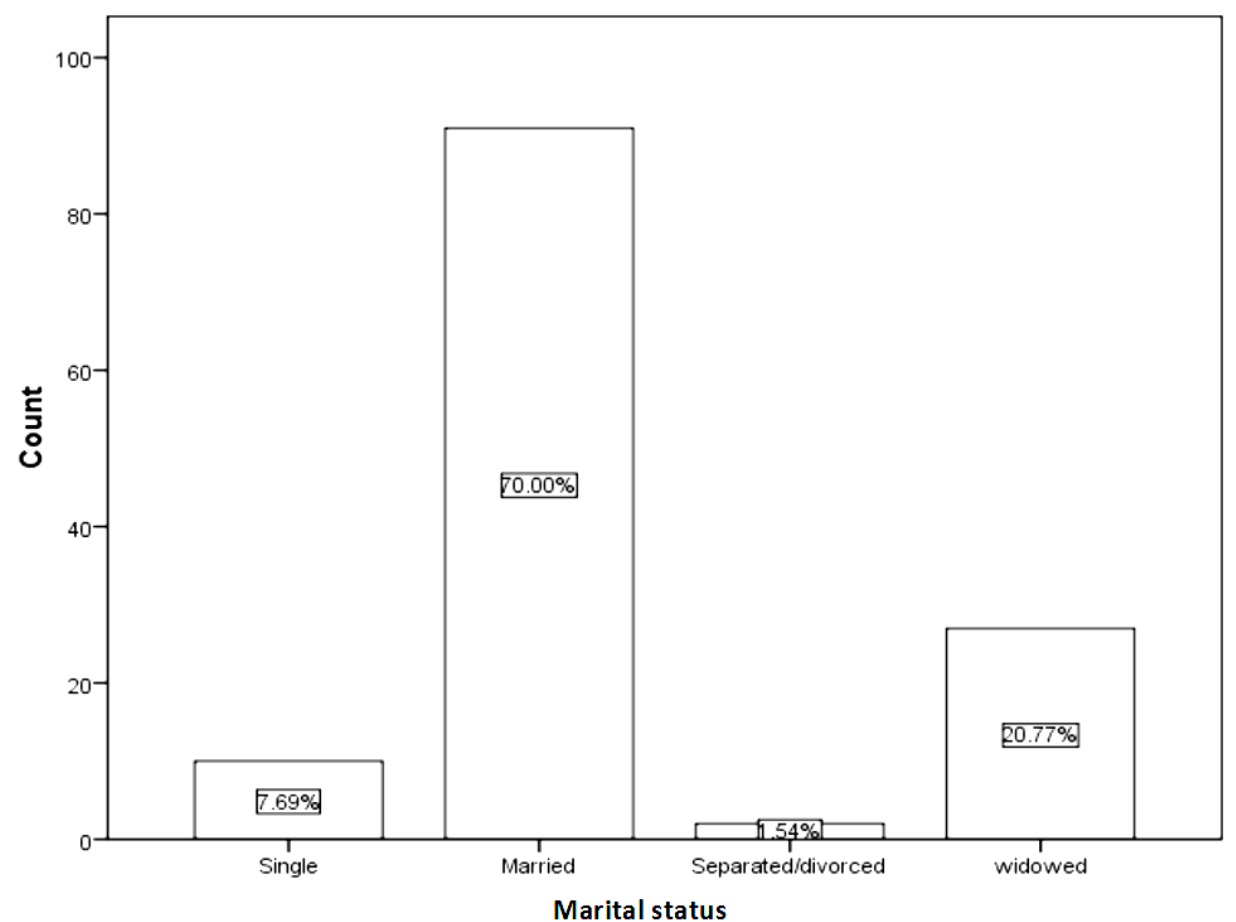

Figure 3: Marital status of farmers

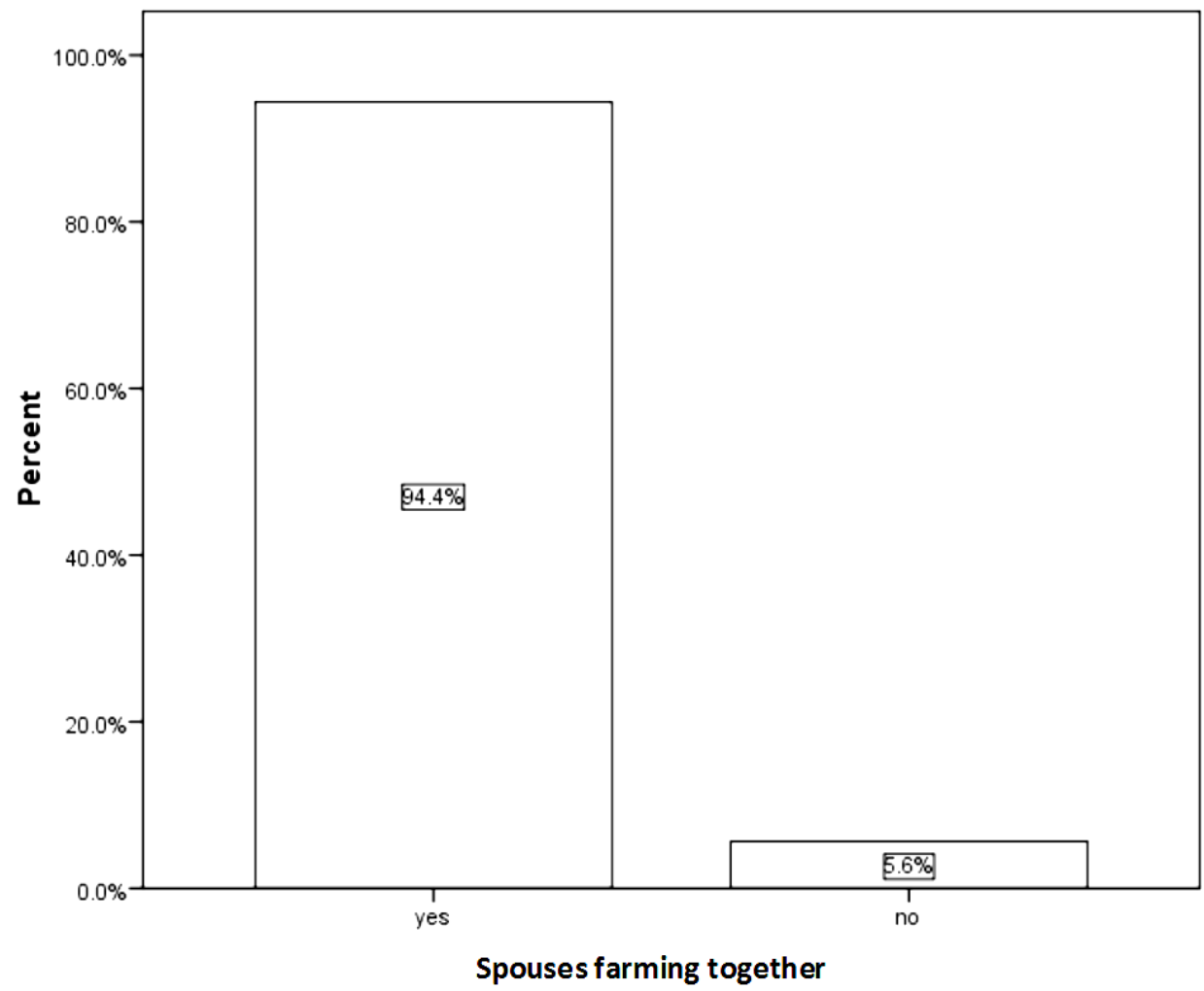

Figure 4: Proportion of spouses that were farming together

Literacy among the respondents was high at $95.3 \%$ (Table 2). These results confirm the high literacy level in Zimbabwe as reported by ZIMSTATS (2011). This is a good indication of high chances of adoption of new information and technology. 
S. Afr. J. Agric. Ext.,

Vol. 44, No. 2, 2016: $121-135$

DOI: http://dx.doi.org/10.17159/2413-3221/2016/v44n2a406

Masuka, Matenda, Chipomho, Mapope,

Mupeti, Tatsvarei \& Ngezimana.

(Copyright)

Table 2: Literacy in the Svosve-Wenimbi area

\begin{tabular}{|l|l|l|}
\hline Level of education & Count & Percentage (\%) \\
\hline Primary & 48 & 37.5 \\
\hline Secondary & 66 & 51 \\
\hline Tertiary & 7 & 5.5 \\
\hline Other & 1 & 0.8 \\
\hline None & 6 & 4.7 \\
\hline
\end{tabular}

Annual income for the households in the area of study ranged from less than US\$100 to over US $\$ 400$ as shown in Figure 5 with the bulk of the farmers (71\%) earning less than US\$101 to US\$400. This show that the households were living on less than US\$2 a day.
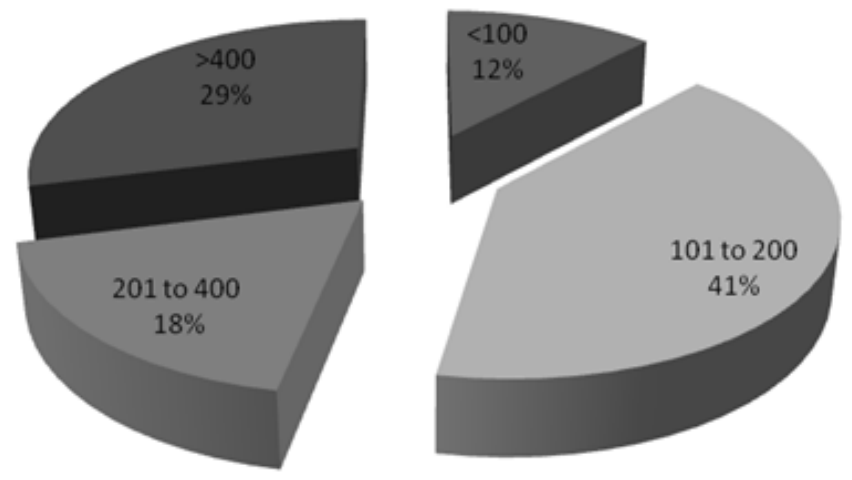

Figure 5: Average household income per annum

Among the 91 respondents who owned cattle out of the 131 interviewed the average number of cattle owned among females and male farmers did not significantly differ $(p<0.05)$. Number of cattle owned ranged from 1 to 40 with average of 7.49 (Table 3).

Table 3: Cattle ownership

\begin{tabular}{|l|l|l|l|l|l|}
\hline Gender & N & Minimum & Maximum & Mean & Std dev \\
\hline Male & 46 & 0 & 30 & 7.04 & 5.978 \\
\hline Female & 44 & 1 & 40 & 8.09 & 7.329 \\
\hline Total & 91 & 0 & 40 & 7.49 & 6.644 \\
\hline
\end{tabular}

\subsection{Farming system}

Svosve-Wenimbi area is characterised by a mixed farming system involving production of cash crops like tobacco and horticultural crops, maize as a staple food crop and some pulses including groundnuts and cowpeas along with the rearing of livestock that include cattle, goats and fowls for domestic and commercial purposes. Average land size in the communal farming area was 3.7 ha ranging from 0.45 ha to 6.4 ha and 23.1 ha in the resettled medium scale farming area ranging from 10 ha to 38.8 ha. The production levels of maize as a staple food crop and a major determinant of food security was evaluated. The survey showed that $82.4 \%$ of the respondents were growing maize using from less than $10 \%$ to over $100 \%$ of the 
S. Afr. J. Agric. Ext.,

Vol. 44, No. 2, 2016: $121-135$

DOI:

Masuka, Matenda, Chipomho, Mapope,

Mupeti, Tatsvarei \& Ngezimana.

(Copyright)

land they own (Table 4) with more than $30 \%$ using up to $20 \%$ and $41.6 \%$ using 21 to $30 \%$ and about $39 \%$ using 31 - to $50 \%$.

Table 4: Proportion of farmers' land used for maize production

\begin{tabular}{|l|l|l|l|l|}
\hline Proportion (\%) & Frequency & Percentage & Valid (\%) & Cumulative (\%) \\
\hline up to 10 & 17 & 13 & 15.7 & 15.7 \\
\hline $11-20$ & 20 & 15.3 & 18.5 & 34.3 \\
\hline $21-30$ & 6 & 4.6 & 5.6 & 39.8 \\
\hline $31-40$ & 23 & 17.6 & 21.3 & 61.1 \\
\hline $41-50$ & 19 & 14.5 & 17.6 & 78.7 \\
\hline $51-60$ & 3 & 2.3 & 2.8 & 81.5 \\
\hline $61-70$ & 4 & 3.1 & 3.7 & 85.2 \\
\hline $71-80$ & 2 & 1.5 & 1.9 & 87 \\
\hline $81-90$ & 1 & 0.8 & 0.9 & 88 \\
\hline $91-100$ & 11 & 8.4 & 10.2 & 98.1 \\
\hline over 100 & 2 & 1.5 & 1.9 & 100 \\
\hline Total & 108 & 82.4 & 100 & \\
\hline Not growing maize & 23 & 17.6 & & \\
\hline Total & 131 & 100 & & \\
\hline
\end{tabular}

Respondents that used 51- to $100 \%$ of their land for maize were $19.5 \%$ while $1.9 \%$ used more than $100 \%$ of the land they owned. The farmers who planted $100 \%$ of their land to maize, owned 0.6 ha and 0.75 ha arable land. With the need to increase their area of production they rented additional land from other farmers. Some farmers (17.6\%) did not grow any maize. The maize yield averaged $1.3 \mathrm{t} \mathrm{ha}^{-1}$ and $1.0 \mathrm{t} \mathrm{ha}^{-1}$ for the communal and resettled farmers respectively ranging from $0.2 \mathrm{tha}^{-1}$ to about $5 \mathrm{t} \mathrm{ha}^{-1}$. The average yield is less than $1.5 \mathrm{tha}^{-1}$ making production levels insufficient to meet the calorie requirements (Smale \& Jayne, 2003) with some farmers producing well below $1 \mathrm{t} \mathrm{ha}^{-1}$ hence the need to promote better production.

Extension is one of the tools that can be used to transfer technology and information that promote better production (Rivera, Qamar \& Crowder, 2001). The use of various modes of extension among farmers was evaluated (Table 5). This study showed that extension through radio programmes was accessible to $57.3 \%$ of the farmers. Field Extension Staff reached 56.5 $\%$. The two mediums of extension were the most common. Agriculture Shows were also relatively popular $(38.2 \%)$ compared to newspapers at $21.4 \%$ and farmer groups at $18.3 \%$. Mobile phones ranked at sixth position (16.8\%) out of the 11 methods evaluated, better than television programmes and company agronomists both utilised by $10.7 \%$ of the farmers and pamphlets used by even less (6.9\%). Mechandisers and Non-governmental organisations (NGOs) were the least popular. Even though a relatively new technology compared to all the other methods, use of $16.8 \%$ for the mobile platforms indicates reasonable adoption and potential for futher adoption of phones for this and other purposes in farming especially consideing the high mobile phone ownership of $94.5 \%$ among the farmers and fair distribution of mobile phones between gender as shown in Figure 6.

Considering mobile phone ownership is high covering almost the entire population, they provide a potential tool for development and transformation. At the time the survey was conducted respondents were already using mobile phones for different activities that support farming. 
S. Afr. J. Agric. Ext.,

Vol. 44, No. 2, 2016: $121-135$

DOI: http://dx.doi.org/10.17159/2413-3221/2016/v44n2a406
Masuka, Matenda, Chipomho, Mapope,

Mupeti, Tatsvarei \& Ngezimana.

(Copyright)

Table 5: Relative use of various platforms extension and information dissemination

\begin{tabular}{|l|l|r|r|}
\hline Extension Platform & Using platform & Count & Percentage (\%) \\
\hline Radio & Yes & 75 & 57.30 \\
& No & 56 & 42.70 \\
\hline Television & Yes & 14 & 10.70 \\
& No & 117 & 89.30 \\
\hline Newspapers & Yes & 28 & 21.40 \\
& No & 103 & 78.60 \\
\hline Pamphlets & Yes & 9 & 6.90 \\
& No & 122 & 93.10 \\
\hline Extension staff & Yes & 74 & 56.50 \\
& No & 57 & 43.50 \\
\hline Company agronomists & Yes & 14 & 10.70 \\
& No & 117 & 89.30 \\
\hline Merchandisers & Yes & 3 & 2.30 \\
& No & 128 & 97.70 \\
\hline Agriculture show & Yes & 50 & 38.20 \\
& No & 81 & 61.80 \\
\hline Farmers group & Yes & 24 & 18.30 \\
& No & 107 & 81.70 \\
\hline NGOs & Yes & 0 & 0.00 \\
& No & 131 & 100.00 \\
\hline Mobile platforms & Yes & 22 & 16.80 \\
& No & 109 & 83.20 \\
\hline
\end{tabular}

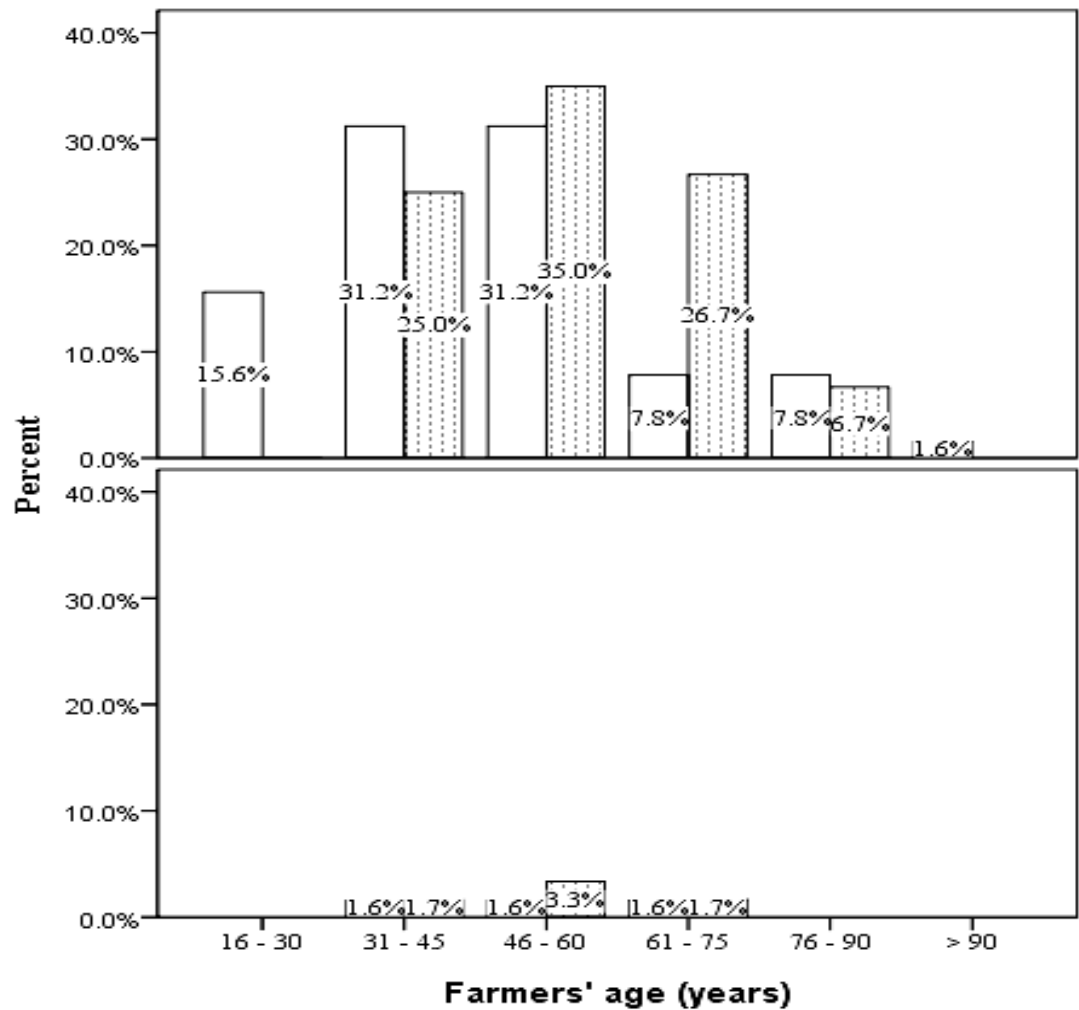

Figure 6: Mobile phone ownership among male and female farmers in Svosve-Wenimbi area 
S. Afr. J. Agric. Ext.,

Vol. 44, No. 2, 2016: $121-135$

DOI: http://dx.doi.org/10.17159/2413-3221/2016/v44n2a406
Masuka, Matenda, Chipomho, Mapope,

Mupeti, Tatsvarei \& Ngezimana.

\subsection{Current use of mobile phones in Agriculture in the Svosve-Wenimbi area}

Literacy level and mobile phone ownership were equally the same across gender at $\mathrm{P}<0.05$ (Table 6).

Table 6: Mobile phone uses in Svosve-Wenimbi Area of Marondera by gender

\begin{tabular}{|l|l|l|l|}
\hline & Female (\%) & Male (\%) & Total (\%) \\
\hline Literacy level & 46.9 & 48.4 & 95.3 \\
\hline Mobile ownership & 45.2 & 49.2 & 94.4 \\
\hline $\begin{array}{l}\text { Farmers using mobile phone for } \\
\text { extension advice }\end{array}$ & 6.0 & 10.0 & 16.0 \\
\hline $\begin{array}{l}\text { Farmers using mobile phone for } \\
\text { agriculture business }\end{array}$ & 25.0 & 32.5 & 57.5 \\
\hline $\begin{array}{l}\text { Farmers perception: mobile } \\
\text { phones useful to farming }\end{array}$ & 37.4 & 35.2 & 72.6 \\
\hline Ecofarmer & 11 & 17.6 & 28.6 \\
\hline Money transfer & 24.8 & 29.9 & 54.7 \\
\hline Farmer groups & 11.1 & 6.5 & 17.6 \\
\hline Internet & 4.7 & 11.3 & 16.0 \\
\hline WhatsApp & 5.3 & 12.6 & 17.9 \\
\hline Facebook & 2.2 & 7.7 & 9.9 \\
\hline Twitter & 0 & 1.1 & 1.1 \\
\hline Improved marketing & 23.9 & 29.2 & 53.1 \\
\hline Shared & 14.5 & 21.0 & 35.5 \\
\hline Mobile platforms useful & 37.4 & 35.1 & 72.5 \\
\hline
\end{tabular}

Some farmers $(54.7 \%)$ were using mobile phones to make payments for inputs and services and to receive payments for farm produce. Farmer groups also utilized mobile phones with $17.6 \%$ of the farmers affiliated to these groups using mobile phones to convene meetings as well as to discuss virtually. With reference to current mobile platforms, $16.0 \%$ were accessing internet on mobile phones, $17.9 \%$ were using the WhatsApp platform, 9.9\% Facebook and $1.1 \%$ Twitter applications. Farmers were not conversant with other social networking platforms, besides these three platforms.

Use of internet in general and advanced internet applications like WhatsApp, Facebook and Twitter was below $20 \%$ but the fact that some farmers were using the platforms is promising since adoption usually start with a few and will spread to others as they share information. Farmers share information as indicated by $35.5 \%$ of the respondents who have shared information on some of the uses of mobile phones that they had found useful in farming. With $53.1 \%$ of the farmers confirming that using mobile phones has improved marketing, more farmers are likely to adopt use of ICTs. Marketing was improved in the sense that farmers could check market prices for inputs or produce and select the best supplier or buyer. Farmers could confirm availability of products and make appointments with buyers or suppliers without travelling and this saved on time travelling costs. Farmers also received updates on products, product prices and produce price from different sources including suppliers, markets and other platforms like Ecofarmer and farming or marketing associations thus saved them on time, travel and assisted in decision making. Most of the farmers $(72.5 \%)$ were of the perception that mobile phones were useful in farming. 
S. Afr. J. Agric. Ext.,

Vol. 44, No. 2, 2016: $121-135$

DOI: http://dx.doi.org/10.17159/2413-3221/2016/v44n2a406
Masuka, Matenda, Chipomho, Mapope,

Mupeti, Tatsvarei \& Ngezimana.

Findings from this study agree with studies conducted elsewhere that farmers received information on mobile phones (Chhachhar et al., 2014; Chhachhar \& Hassan, 2013; Martin \& Abbott, 2008; Mwakaje, 2010; Nyamba \& Mlozi, 2012; Tadesse \& Bahiigwa, 2015) that enabled them to make informed decisions (Nyamba \& Mlozi, 2012; Tadesse \& Bahiigwa, 2015), got better market prices (Mwakaje, 2010), weather information (Nyamba \& Mlozi, 2012), saved time and transport costs by overcoming geographical distances through voice calls and text messaging (Deloitte, 2012; Nyamba \& Mlozi, 2012) consulted agriculture extension staff or advisors (Martin \& Abbott, 2008; Oladele, 2015) and utilized mobile financial transactions (Deloitte, 2012; Nyamba \& Mlozi, 2012). The use of other mobile phone applications like internet and WhatsApp were reasonable for rural population. These show potential for adoption of specific farming applications that are being used elsewhere for general crop agronomy, fertilizer, weed, pest and disease management, livestock management, market and farmer location for specific products as well as alternative markets and market prices.

\subsection{The Logit model results}

The logit model was tested for goodness of-fit considering gender, level of education, marital status, cattle owned, types of crops grown, sources of extension and farm income. All the measures in Tables 7 and 8 show the overall models' goodness-of-fit tests. Results show that the model specification was overall good.

Table 7: Model Summary

\begin{tabular}{|l|l|l|l|}
\hline Step & -2 Log likelihood & Cox \& Snell R Square & Nagelkerke R Square \\
\hline 1 & $147.469 \mathrm{a}$ & 0.206 & 0.275 \\
\hline
\end{tabular}

Correlation tests were conducted among explanatory variables to check for any possibilities of relationships. The results show that correlations coefficients among explanatory variables are very low, indicating good model specification.

Table 8: Hosmer and Lomeshow Test

\begin{tabular}{|l|l|l|l|}
\hline Step & Chi-square & DF & Sig. \\
\hline 1 & 20.315 & 8 & 0.009 \\
\hline
\end{tabular}

Most of the variables tested had the expected hypothesized signs (Table 8).

Table 9: Mobile phone use logistic regression model

\begin{tabular}{|l|r|r|r|r|r|r|}
\hline & \multicolumn{1}{c|}{ B } & \multicolumn{1}{c|}{ S.E. } & \multicolumn{1}{c|}{ Wald } & \multicolumn{1}{c|}{ DF } & \multicolumn{1}{c|}{ Sig. } & \multicolumn{1}{|c|}{$\operatorname{Exp(B)}$} \\
\hline Gender & -0.035 & 0.434 & 0.006 & 1 & 0.937 & 0.966 \\
\hline Age & -0.030 & 0.013 & 5.395 & 1 & 0.020 & 0.971 \\
\hline Years of education & -0.027 & 0.121 & 0.050 & 1 & 0.823 & 0.973 \\
\hline Marital status & -0.055 & 0.470 & 0.014 & 1 & 0.906 & 0.946 \\
\hline Cattle owned & 0.072 & 0.038 & 3.600 & 1 & 0.058 & 1.074 \\
\hline Commercial activities & -1.250 & 0.443 & 7.951 & 1 & 0.005 & 0.287 \\
\hline Source of extension & -0.716 & 0.706 & 1.030 & 1 & 0.310 & 0.489 \\
\hline Total income & 0.003 & 0.002 & 4.198 & 1 & 0.040 & 1.003 \\
\hline Constant & 2.306 & 1.403 & 2.700 & 1 & 0.100 & 10.032 \\
\hline
\end{tabular}


From the logit regression results in Table 9, cattle owned and total income fit to work positively to influence use of mobile technology while gender, age, years of education, commercial activities and source of extension fit to work negatively to influence the use of mobile technologies among smallholder farmers in Marondera.

Table 9 shows the results of the variables that were considered in the model. Gender, marital status, years of education, number of cattle owned and the source of extension information did not significantly affect mobile phone use for farming purposes at $\mathrm{p}<0.05$. Young farmers used mobile technologies in farming than their older counterparts $(\mathrm{p}<0.05)$. New technologies are more appreciated by the generation in which they are introduced.

Farmers who were inclined towards commercial activities (especially the growing of tobacco and horticulture) were more likely to adopt the use of mobile technologies in agriculture ( $\mathrm{p}<$ 0.01). From the regression results, mobile phone use was higher among the farmers who were less inclined towards commercial activities. The expectation is that farmers need to be in constant interaction with input and outputs markets for them to farm viably. Mobile phones offer them an opportunity to have this interaction with minimal transaction costs and without disturbing timely production activities on farm through constant visits to output and input markets.

As supported by the results from the wealth factor, income has a positive and significant influence on use of mobile technologies in agriculture $(\mathrm{p}<0.05)$. Higher disposable incomes results in higher expenditures and more considerations for non-food items such as mobile phones as understood from Maslow's hierarchy of needs (Maslow, 1970). More disposable income may have made mobile phones more affordable for the farmers.

\section{CONCLUSION AND RECOMMENDATION}

Svosve-Wenimbi was characterized by mixed farming that included mixed food (field and horticulture) and commercial crop production as well as the rearing of various livestock. Mobile phone ownership was high at $94.5 \%$ and use for agriculture business that included acquiring production and market information, planning meetings and financial transactions was $57.5 \%$. With $72.5 \%$ farmers believing that mobile phones were useful in farming, probability of adoption of current uses at the time of study among non users as well as the new applications and uses among all farmers is high. Adoption of mobile phone use for farming purposes was influenced by age, commercial farming activities and total income.

Extension or farmer schools to raise awareness on the different uses of mobile phones in farming may improve adoption of use of mobile phones in farming. Researchers and extension staff can also develop some simple applications that can be used by farmers to verify agronomic, livestock practices and recommendations as well as market locations and prices without the need to travel for consultation with advisors, suppliers and buyers. Mobile operators are also constantly improving the technology with value addition of applications that make use of artificial intelligence and improvements in mobile money transfer services that facilitate greater financial inclusions within farmers. This will promote better production and marketing and reduce transport costs. Using mobile phones in extension will achieve the following: curb transport challenges where in some cases extension staff may have no vehicles or sufficient fuel allocations and enable farmers to consult and extension to advise in emergency cases where the farmer/ extension officer may fail to get to the extension officer/ 
S. Afr. J. Agric. Ext.,

Vol. 44, No. 2, 2016: $121-135$

DOI: http://dx.doi.org/10.17159/2413-3221/2016/v44n2a406

Masuka, Matenda, Chipomho, Mapope,

Mupeti, Tatsvarei \& Ngezimana.

farmer on time to save livestock or crops; enable extension to disseminate information rapidly and efficiently over the phone compared to organising meetings or farm visits; enable farmers to get current weather, market, literature and production information; makes coordination of extension activities like training and shows easier; extension officers will save time lost in travel and use it on advisory service; extensionists can also consult quickly with specialists and give farmers advice on time; farmers save time when they resolve small issues by chat or voice call consultations. On the other hand, if most of the extension work is done via mobile phone service with few or no field visits extension staff may lose relationships with farmers and may lack a true picture of what is on the ground. Use of mobile phones should be maximized in extension but should be combined with conventional extension approaches involving farmer-extension contact and farm visits. Farmers therefore need to embrace the knowledge that not only can the mobile device be used for communication purposes but it can bridge the time gap with regards to agronomic information dissemination.

\section{ACKNOWLEDGEMENT}

The authors are grateful to The University of Zimbabwe for funding the pilot project survey that aimed to identify challenges facing small holder farmers and the potential use of modern ICT in agriculture production and marketing in Svosve-Wenimbi Area of Marondera District in Mashonaland East Province, Zimbabwe. The views and opinions expressed in this paper are that of the authors and do not reflect the views and stands of the institutions.

\section{REFERENCES}

CHHACHHAR, A. R., QURESHI, B., KHUSHK, G. M. \& MAHER, Z. A. 2014. Use of Mobile Phone among Farmers for Agriculture Information. European Journal of Scientific Research, 119(2), 265-271.

CHHACHHAR, R. A. \& HASSAN, M. S. 2013. The Use of Mobile Phone Among Farmers for Agriculture Development. International Journal of Scientific Research, 2(6), 95-98.

DELOITTE. 2012. eTransform Africa: Agriculture Sector Study Sector Assessment and Opportunities for ICT.

http://siteresources.worldbank.org/EXTINFORMATIONANDCOMMUNICATIONAN DTECHNOLOGIES/Resources/282822-1346223280837/Agriculture_FullReport.pdf Accessed 3-12-2015

ECONET. 2015. Ecofarmer. https://www.econet.co.zw/ecofarmer

ETRANSFORM AFRICA. 2012. The Transformational Use of Information and Communication Technologies in Africa. http://www.infodev.org/en/Publication.1162.html Accessed 4-12-2015

EWING, J., QUIGLESS, M., CHEVROLIER, N., VERGHESE, T. \& LEENDERSTE, M. 2014. ICT competitiveness in Africa, (February), 1-28. World Bank. http://documents.worldbank.org.ezproxy.uct.ac.za/curated/en/2014/01/19556538/ictcompetitiveness-africa

FAO. 2006. What we do: Reduce rural poverty. http://www.fao.org/newsroom/en/news/2006/1000472/index.html Accessed 3-12-2015

FAO. 2010. Global Partnership Initiative for Plant Breeding Capacity Building. Plant breeding programs in Zimbabwe. http://www.fao.org/in-action/plant-breeding/ourpartners/africa/zimbabwe/en/ Accessed 3-04-2016

FAO. 2015. The State of Food and Agriculture 2015 (SOFA): Social Protection and Agriculture: Breaking the Cycle of Rural Poverty. FAO, Rome. 
S. Afr. J. Agric. Ext.,

Vol. 44, No. 2, 2016: $121-135$

DOI: 1

FOSU-MENSAH, B. Y., VLEK, P. L. G. \& MACCARTHY, D. S. 2012. Farmers' perception and adaptation to climate change: A case study of Sekyedumase district in Ghana. Environment, Development and Sustainability, 14, 495-505. Doi:10.1007/s10668-0129339-7

IREFIN, I. A., ABDU-AZEEZ, I. A. \& TIJANI, A. A. 2012. An Investigative Study of the Factors Affecting the Adoption of. Australian Journal of Business and Management Research, 2(02), 1-9.

JENSEN, M. 2001. ICT in Africa: A Status Report, 86.

KRISHAN, J. B. 2000. "Information Communication Technology (ICTs) for Rural Development and Food Security". http://www.aptsec.org. Accessed 3-04-2016

MARTIN, B. \& ABBOTT, E. 2008. Development Calling: The Use of Mobile Phones in Agriculture Development in Uganda. Greenlee School of Journalism and Communication, (5) 1-13. Iowa State University.

MASLOW, A. H. 1970. Motivation and personality. New York: Harper \& Row

MWAKAJE, A. G. 2010. Information and Communication Technology for Rural Farmers Market Access in Tanzania. Journal of Information Technology Impact, (10):111-128.

NYAMBA, S. Y. \& MLOZI, M. R. S. 2012. Factors Influencing the Use of Mobile Phones in Communicating Agricultural Information: A Case of Kilolo District, Iringa, Tanzania. International Journal of Information Technology Research, 2(7), 558-563.

OLADELE, O. I. 2015. Effect of Information Communication Technology (ICT) on Agricultural Information Access Among Extension Officers in North West Province South Africa. S. Afr. J. Agric. Ext. 43 (2), 30-41.

POTRAZ. 2014. Postal and telecommunications sector performance report. Third quarter 2014 http://www.potraz.gov.zw/images/documents/3rd_Quarter_2015.pdf

POTRAZ. 2014. Postal and telecommunications sector performance report. First quarter 2014 http://www.potraz.gov.zw/images/documents/1st_Quarter_2015.pdf Accessed 8-12-2015

RIVERA, W., QAMAR, M. K. \& CROWDER, L. VAN. 2000. Agricultural and Rural Extension Worldwide: Options for Institutional Reform in the Developing Countries Agricultural and Rural Extension Worldwide: Options for Institutional Reform in the Developing Countries.

SMALE, M. \& JAYNE, T. 2003. Maize in Eastern and Southern Africa: "seeds" of success in retrospect IFPRI. Retrieved from

http://www.researchgate.net/publication/5056187_Maize_in_Eastern_and_Southern_Afri ca_seeds' of success in retrospect/file/79e4151144e3befba8.pdf

TADESSE, G. \& BAHIIGWA, G. 2015. Mobile Phones and Farmers' Marketing Decisions in Ethiopia. World Development, 68, 296-307.

TECHNOMAG. 2014. Zimbabwe No1 in Sub-Saharan African Countries. http://www.technomag.co.zw/2014/05/13/zimbabwe-no1-in-sub-saharan-africancountries/\#sthash.xuKYik19.dpbs Accessed 3-12-2015

TECHZIM. 2014. Zimbabwe's mobile penetration $106 \%$ as Econet grows to 9 million subscribers. http://www.techzim.co.zw/2014/07/zimbabwes-mobile-penetration-106econet-grows-9-million-subscribers/

TECHZIM. 2015. By the numbers: 6 interesting facts about telecoms \& internet in Zimbabwe http://www.techzim.co.zw/2015/02/numbers-6-interesting-facts-telecoms-internetzimbabwe/ Accessed 3-12-2015

WEI, L. \& ZHANG, M. 2008. The adoption and use of mobile phone in rural China: A case study of Hubei, China. Telematics and Informatics, 25(3), 169-186.

WORLD BANK. 2012. eTransform Africa: Financial Services Sector Study. World Bank.

WORLD BANK. 2015. 2014 Gross Domestic Product. World Bank Development Indicators Database, World Bank, 2015. 
S. Afr. J. Agric. Ext.,

Vol. 44, No. 2, 2016: $121-135$

DOI: http://dx doi.org/10.1715

Mupeti, Tatsvarei \& Ngezimana.

(Copyright)

ZIMSTATS. 2011. Distance Education Report, (October), 3-85. ZIMSTAT, Zimbabwe National Statistics Agency. 